\title{
DAMPAK ATTACHMENT IBU-ANAK BAGI PERKEMBANGAN PSIKOSOSIAL ANAK DI MASA REMAJA
}

\author{
Jeny Kusdemawati \\ Bimbingan Penyuluhan Islam IAIN Ponorogo \\ jenyyk.2@gmail.com
}

\begin{abstract}
Abstrack
Attachment is an emotional bond that is built by parents or caregivers with children. There are two types of attachments that secure attachment and insecure attachment. This study discusses the impact of mother-daughter attachment of exTenaga Kerja Wanita (TKW) for their psychosocial development in adolescence. The formulation of the problem in this study is how the attachment pattern of former TKW mothers with their daughters is, and how is the impact of motherdaughter attachments of former TKWs on the psychosocial development of children in adolescence. The purpose of this study is to find out the attachment pattern of former TKW mothers with their daughters, and to explain the impact motherchild attachment of former TKW for the psychosocial development of children in adolescence. In this study, the method used is a qualitative research method using a case study research type. This research is located in MA Al-Islamiyah Uteran Geger Madiun by using data collection techniques in the form of observation and interviews. In this study the authors took five sources to dig deeper information. The five resource persons were one teenage girl in grade 10 and one girl in grade 12, two former TKW mothers from the two students, and one counseling teacher. The results of the study showed that the pattern of attachment of a former TKW mother with her daughter was insecure attachment. The impact of insecure attachment for children's psychosocial is a lack of confidence in children which causes them to always harbor feelings and be more closed about personal problems.
\end{abstract}

Keywords: Impact, Attachment, Former TKW Mother, Adolescent Psychosocial

\begin{abstract}
Abstrak
Attachment adalah suatu ikatan emosional yang dibangun oleh orang tua atau pengasuh dengan anak. Ada dua jenis attachment yakni secure attachment (kelekatan aman) dan insecure attachment (kelekatan tidak aman). Penelitian ini membahas dampak kelekatan ibu-anak mantan TKW bagi perkembangan psikososialnya di masa remaja. Rumusan masalah dalam penelitian ini adalah bagaimana pola attachment ibu mantan TKW dengan putrinya, dan bagaimana dampak attachment ibu-anak mantan TKW bagi perkembangan psikososial anak di masa remaja. Adapun tujuan dalam penelitian ini adalah mengetahui pola attachment ibu mantan TKW dengan putrinya, dan menjelaskan dampak attachment ibu-anak mantan TKW bagi perkembangan
\end{abstract}


psikososial anak di masa remaja. Dalam penelitian ini metode yang digunakan adalah metode penelitian kualitatif dengan menggunakan tipe penelitian studi kasus. Penelitian ini berlokasi di MA Al-Islamiyah Uteran Geger Madiun dengan menggunakan teknik pengumpulan data berupa observasi dan wawancara. Dalam penelitian ini penulis mengambil lima narasumber untuk menggali informasi lebih dalam. Lima narasumber tersebut adalah satu remaja putri kelas 10 dan satu remaja putri kelas 12, dua ibu mantan TKW dari kedua siswa tersebut, dan satu guru BK. Hasil penelitiam menunjukkan bahwa pola kelekatan ibu mantan TKW dengan putrinya adalah insecure attachment. Dampak dari insecure attachment bagi psikososial anak adalah rasa tidak percaya diri pada anak yang menyebabkannya selalu memendam perasaannya dan lebih tertutup perihal masalah pribadi.

\section{Kata Kunci: Dampak, Attachment, Ibu Mantan TKW, Psikososial Remaja}

\section{PENDAHULUAN}

Orang tua merupakan figur yang sangat penting untuk perkembangan seorang anak. Orang tua merupakan komponen keluarga yang terdiri dari ayah dan ibu, hubungan orang tua terjadi karena hubungan perkawinan yang sah dan kemudian membentuk sebuah keluarga. Orang tua bertanggung jawab untuk mendidik, mengasuh, dan membimbing anak-anaknya untuk mencapai perkembangan agar mampu berinteraksi dengan masyarakat.

Orang tua berperan penting dalam mewujudkan keberhasilan anak, baik secara psikologis, kognitif maupun fisik. Peran orang tua yang paling berarti bagi perkembangan anak adalah peran seorang ibu. Setelah anak lahir, ia akan memulai interaksi pertama kali dengan ibu. Interaksi ini biasa disebut dengan attachment atau kelekatan. Istilah attachment dicetuskan pertama kali oleh John Bowlby.

Menurut Bowlby attachment merupakan suatu ikatan emosional yang dibangun oleh orang tua atau pengasuh dengan anak. Attachment berguna untuk meningkatkan rasa aman, nyaman dan rasa percaya diri pada kehidupan selanjutnya. Apabila anak mendapatkan kelekatan yang nyaman dan aman maka mereka akan merasa percaya diri dan dapat berinterksi dengan orang lain. Sebaliknya, jika anak kurang mendapatkan kelekatan maka akan merasa tidak percaya diri serta tidak merasa aman jika berinteraksi dengan orang lain. ${ }^{1}$

1 Khaerina Nabila Khaeruddin dan Ahmad Ridfah, "Kelekatan Remaja dengan Ibu yang Bekerja,” Jurnal Psikologi Talenta, 1 (2020)., 2 
Terdapat dua macam kelekatan yaitu kelekatan secure dan kelekatan insecure. Kelekatan secure dapat terjadi apabila orang tua membiarkan anak untuk mengeksplorasi lingkungannya tanpa mengalami rasa cemas, serta orang tua memiliki hubungan yang baik dengan anak. Kelekatan insecure merupakan bentuk kelekatan yang tidak aman dimana orang tua berusaha untuk membatasi maupun mengisolasi anak. $^{2}$

Kelekatan akan berlanjut sampai anak mencapai usia remaja. Remaja menurut Santrock adalah masa perkembangan transisi atau masa peralihan, mereka bukan kanak-kanak dan bukan orang dewasa. Usia remaja antara 12 hingga 22 tahun. Remaja mengalami berbagai macam perubahan baik secara fisik, emosional, persepsi akan nilai-nilai yang berkembang dalam masyarakat. ${ }^{3}$

Perubahan yang dialami remaja meliputi fisik, kognitif, dan sosial dapat berpengaruh kepada relasi ibu dengan remaja. Ciri yang paling menonjol dari remaja yang mempengaruhi relasinya dengan ibu adalah perjuangan untuk memperoleh otonomi secara fisik maupun psikologis. ${ }^{4}$ Akibat dari perubahan tersebut dapat berdampak pula pada hubungan kelekatan ibu dan remaja. Hal tersebut terjadi karena mereka mulai mempertanyakan dan menentang pandangan-pandangan orang tua terutama ibu, serta mereka lebih memilih untuk mengembangkan ide-ide mereka sendiri. $^{5}$

Attachment ibu dan anaknya semakin diuji apabila mereka terpisah jarak. Dimana sang ibu harus bekerja jauh dari rumah untuk memenuhi kebutuhan seharihari. Fenomena ibu atau wanita yang bekerja di luar negeri biasa dikenal dengan Tenaga Kerja Wanita (TKW). Berdasarkan UU RI No. 39 Tahun 2004 TKI merupakan setiap warga negara Indonesia yang memenuhi syarat sebagai pencari kerja yang akan bekerja di luar negeri yang terdaftar di instansi Pemerintah Kabupaten atau Kota. Sehingga merujuk pada pengertian tersebut, TKW merupakan

\footnotetext{
${ }^{2}$ Ibid.,2

3 Rosleny Marliani, Psikologi Perkembangan (Bandung: CV. Pustaka Setia, 2015). 165-168

${ }^{4}$ Desmita, Psikologi Perkembangan (Bandung: PT. Remaja Rosdakarya, 2016)., 217

${ }^{5}$ Desmita, Psikologi Perkembangan., 218
} 
setiap wanita yang mampu melakukan pekerjaan guna menghasilkan sesuatu berupa jasa maupun barang untuk memebuhi kebutuhan. ${ }^{6}$

Dalam fenomena TKW tersebut, ibu bertugas memenuhi fungsi keluarga yakni fungsi ekonomi. Akibat dari fenomena tersebut adalah pola kelekatan terjadi secara tidak sempurna karena anak akan diasuh oleh figur lekat pengganti seperti ayah, kakek, nenek, maupun kerabat dari anak tersebut. Meskipun peran-peran tersebut sudah digantikan oleh orang-orang terdekat, tetap saja peran tersebut berbeda dengan peran yang diberikan seorang ibu.

Dampak yang ditimbulkan dari fenomena tersebut juga berpengaruh kepada perkembangan anak di kehidupan selanjutnya saat ibu sudah menjadi mantan TKW. Seperti hubungan yang tidak harmonis dan sering terjadi perselisihan. Selain itu, anak yang tidak mendapat kelekatan aman dengan sang ibu akan mengalami berbagai permasalahan di lingkungannya. Salah satu lingkungan yang terdampak dari hubungan tersebut adalah lingkungan sekolah, utamanya SMA atau MA (Madrasah Aliyah).

Masa Madrasah Aliyah (MA) merupakan masa dimana anak mulai banyak berinteraksi dengan orang lain. Interaksi tersebut dapat berupa interaksi positif maupun negatif. Interaksi positif merupakan dampak dari kelekatan aman, sedangkan interaksi negatif merupakan dampak dari kelekatan tidak aman. Madrasah aliyah yang berbasis agama diharapkan dapat membentuk akhlak siswa, terutama akhlak kepada orang tua.

Bekal dari madrasah saja tidak mencukupi apabila dari lingkungan keluarga tidak baik. Kelekatan pada masa kecil sangat diperlukan remaja sebagai modal untuk mengembangkan dirinya di lingkungan madrasah. Dampak yang ditimbulkan dari ketidak hadiran ibu adalah hubungan keduanya menjadi tidak harmonis, sering terjadi perselisihan dan berdampak pada kualitas siswa ketika di madrasah.

\section{METODE PENELITIAN}

Dalam penelitian ini menggunakan metode penelitian kualitatif yang menggunakan tipe penelitian studi kasus. Studi kasus merupakan keterikatan atau

\footnotetext{
${ }^{6}$ Ekapti Wahjuni Djuwitaningsih, "Pola Komunikasi Keluarga dan Pola Asuh Anak (TKW),"
} Jurnal Penelitian Komunikasi dan Opini Publik, 1 (Juli 2018)., 69 
kepedulian peneliti akan suatu kasus. Penelitian ini bertujuan untuk memahami secara utuh tentang fenomena yang terjadi di lapangan. ${ }^{7}$ Penelitian ini terfokus pada attachment ibu-anak pasca ibu menjadi TKW dan dampak attachment ibu-anak mantan TKW bagi perkembangan anak di masa remaja.

Penelitian ini berlokasi di lingkungan Madrasah Aliyah Al-Islamiyah Desa Uteran, Kecamatan Geger, Kabupaten Madiun. Dalam penelitian ini menggunakan data primer berupa observasi dan wawancara dengan lima informan. Informan tersebut adalah dua remaja putri beserta ibu dan satu guru BK di MA Al-Islamiyah, kemudian peneliti akan mencatat dalam bentuk catatan tertulis.

\section{HASIL PENELITIAN DAN PEMBAHASAN}

Pola attachment ibu mantan TKW dengan putrinya di MA Al-Islamiyah Uteran, Geger, Madiun

Berdasarkan hasil wawancara dan observasi yang peneliti lakukan terdapat dua siswi yang memiliki pola kelekatan insecure attachment dengan ibunya di MA AlIslamiyah. Siswi tersebut berinisial FA dan AL.

\section{Pola attachment FA dengan ibunya.}

Pola attachment yang terjadi antara FA dengan ibunya adalah insecure attachment atau kelekatan tidak aman. Pola kelekatan yang tidak aman tersebut ditunjukkan FA dengan melakukan perilaku menghindar dari sang ibu. Perilaku menghindar tersebut dilakukan FA karena ia merasa tidak nyaman apabila dekat sang ibunya. FA merasa tidak nyaman karena dia jarang bertemu dengan sang ibu yang bekerja di luar negeri (menjadi TKW), sehingga dia masih belum memiliki kedekatan dengan sang ibu. Bukan hanya tidak nyaman, FA juga merasa tidak percaya diri karena ia selalu disalahkan ibunya ketika berbuat sesuatu. Ibunya sendiri juga tidak memberikan kepercayaan kepada FA, karena merasa bahwa FA belum mampu dalam melakukan sesuatu dengan baik. Hal itu muncul karena tidak

\footnotetext{
${ }^{7}$ Kristi Poerwandari, Pendekatan Kualitatif Untuk Penelitian Perilaku Manusia (Depok: LPSP3
} Universitas Indonesia, 2017)., 123-125 
adanya kelekatan yang baik antara ibu dengan anak. Kelekatan yang tidak baik tersebut muncul karena kurangnya interaksi antara ibu dan anak yang memunculkan tidak adanya kenyamanan antara satu dengan lainnya.

\section{Pola attachment AL dengan ibunya.}

Kelekatan yang dialami oleh remaja AL juga sama dengan remaja FA. Remaja AL memiliki kelekatan insecure attachment atau kelekatan tidak aman dengan ibunya. Pola kelekatan tersebut ditunjukkan dengan perilaku dan pernyataan AL yang menunjukkan rasa tidak aman ketika bersama ibu. Perilaku tersebut ditunjukkan AL dengan sering berselisih pendapat dengan ibunya dan kurangnya rasa percaya pada ibu. Insecure attachment yang dialami AL muncul karena kurangnya komunikasi antara AL dengan ibunya. Kurangnya komunikasi tersebut muncul karena AL dan ibunya tidak terjalin dengan baik semenjak ibunya berada di luar negeri, sehingga hal tersebut berlanjut setelah ibu AL menjadi mantan TKW.

\section{Dampak attachment ibu-anak bagi perkembangan anak di masa remaja}

Kelekatan sebenarnya memiliki dampak yang positif selama kelekatan tersebut merupakan kelekatan yang sehat. Kelekatan yang sehat adalah kelekatan yang menumbuhkan rasa aman, dan nyaman bagi anak. Kelekatan sehat atau kelekatan aman juga dapat menumbuhkan rasa percaya diri, membuat anak mudah beradaptasi, mampu mngembangkan diri di lingkungan, disiplin serta dapat menumbuhkan kemampuan kognitif anak. ${ }^{8}$ Adapun penjelasan terkait dampak kelekatan bagi remaja sebgai berikut:

\section{Responden FA}

Responden FA yang memiliki jenis kelekatan tidak aman berdampak negatif terhadap perkembangan psikososialnya. Kelekatan tersebut berdampak pada relasinya dengan orang lain. FA mengaku bahwa dirinya menjadi pribadi yang tertutup dan sulit untuk percaya dengan orang lain. Pernyataan tersebut ditunjukkan FA dengan tidak

${ }^{8}$ Ningrum, "Hubungan Kelekatan Orang Tua-Anak Dengan Kemandirian Emosional Pada Remaja.", 8 
pernah bercerita tentang permasalahan pribadi selain dengan guru BK. FA lebih mempercayakan permasalahan pribadinya kepada guru BK daripada orang lain. Perilaku tersebut ia lakukan karena FA merasa bahwa apabila bercerita dengan orang tua atau teman maka mereka tidak dapat memahami keadaannya.

2. Responden $\mathrm{AL}$

Responden AL juga memiliki kelekatan yang tidak aman dengan ibunya. Kelekaan tersebut juga berdampak pada perekembangan psikososial AL yang menjadi pribadi yang tertutup. Menurut pengamatan yang dilakukan peneliti, AL termasuk anak yang kurang ekspresif. Perilaku tersebut ditunjukkan $\mathrm{AL}$ yang selalu menghindar apabila berbicara dengan sang ibu dan cenderung memendam perasaannya sendiri. Sebagai bentuk pelampiasan akan hal tersebut AL memilih untuk bergaul dengan teman sebaya. Pergaulan tersebut juga menimbulkan perasaan cemas ibu AL karena takut AL akan mengalami salah pergaulan.

\section{PENUTUP}

Pola attachment antara ibu mantan TKW dengan putrinya di MA Al-Islamiyah adalah insecure attachment atau kelekatan tidak aman. Kelekatan tidak aman tersebut terjadi karena kurangnya pola komunikasi antara ibu dan anak, intensitas kebersamaan ibu dan anak, serta tidak adanya rasa percaya satu sama lain. Dampak insecure attachment ibu-anak bagi perkembangan psikososial anak di usia remaja di MA Al-Islamiyah adalah adanya rasa tidak percaya diri pada anak. Rasa tidak percaya diri tersebut juga mempengaruhi pada relasi mereka kepada orang lain. Mereka cenderung memendam perasaannya masing-masing dan lebih tertutup perihal permasalahan pribadi. 


\section{DAFTAR RUJUKAN}

Desmita, Psikologi Perkembangan (Bandung: PT. Remaja Rosdakarya, 2016).

Djuwitaningsih, Ekapti Wahjuni, "Pola Komunikasi Keluarga dan Pola Asuh Anak (TKW)," Jurnal Penelitian Komunikasi dan Opini Publik, Vol 22, No.1 (Juli 2018), (Online)., (https://jurnal.kominfo.go.id) diakses pada 14 Juni 2021

Khaeruddi, Khaerina Nabila ,Ahmad Ridfah, Kelekatan Remaja dengan Ibu yang Bekerja, Jurnal Psikologi Talenta, Vol 3, No.1 (September 2017)., (Online), (https://doi.org/10.26858/talenta.v3i1.13065) diakses pada 15 Juni 2021

Marliani, Rosleny, Psikologi Perkembangan (Bandung: CV. Pustaka Setia, 2015).

Ningrum, Rizqi Setya Widya. Hubungan Kelekatan Orang Tua-Anak Dengan Kemandirian Emosional Pada Remaja. Skripsi Strata 1 Fakultas Psikologi Program Studi Psikologi Universitas Muhamadiyah Malang 2017, (Online), (http://eprints.umm.ac.id) diakses pada 15 Juni 2021

Poerwandari, Kristi, Pendekatan Kualitatif Untuk Penelitian Perilaku Manusia (Depok: LPSP3 Universitas Indonesia, 2017). 